\title{
Autotrophic Growth and Nitrogen Fixation in Derxia gummosa
}

\author{
By H. N. RAVI SHANKAR, ${ }^{1}$ I. R. KENNEDY ${ }^{2}$ AND P. B. NEW ${ }^{*}$ \\ ${ }^{1}$ Department of Microbiology, G08, Biochemistry Building, University of Sydney, \\ New South Wales, Australia 2006 \\ ${ }^{2}$ Department of Agricultural Chemistry, University of Sydney, New South Wales, Australia 2006
}

(Received 4 November 1985; revised 19 February 1986)

Initial attempts to grow $\mathrm{N}_{2}$-fixing Derxia gummosa autotrophically on $\mathrm{H}_{2}, \mathrm{CO}_{2}, \mathrm{O}_{2}$ and $\mathrm{N}_{2}$ in a closed system yielded variable results. Poor growth was found to be due to rapid $\mathrm{O}_{2}$ depletion and the requirement for an agar surface. In a closed system, $\mathrm{C}_{2} \mathrm{H}_{2}$ reduction assays could not be carried out due to complete consumption of $\mathrm{H}_{2}$. Hence a flow-through culturing technique was developed to supply gases at a constant partial pressure and to perform $\mathrm{C}_{2} \mathrm{H}_{2}$ reduction assays in a continuous flow system. Hydrogenase of autotrophic D. gummosa was not inhibited by $\mathrm{C}_{2} \mathrm{H}_{2}$, even at $0.5 \mathrm{~atm}$, and the $K_{\mathrm{m}}$ of hydrogenase for $\mathrm{H}_{2}$ was approximately $0.15 \mathrm{~atm}$. The effects of $\mathrm{O}_{2}$ and $\mathrm{H}_{2}$ on $\mathrm{C}_{2} \mathrm{H}_{2}$ reduction were examined, using the flow-through assay system. The rate of $\mathrm{C}_{2} \mathrm{H}_{2}$ reduction decreased below 0.074 atm $\mathrm{H}_{2}$, suggesting that ATP and reductant supply were limiting the nitrogenase activity.

\section{INTRODUCTION}

Derxia gummosa, an obligate aerobe of the family Azotobacteraceae, is described as a 'typical awkward nitrogen-fixer' (Hill \& Postgate, 1969) because its growth under $\mathrm{N}_{2}$-fixing conditions is variable and unreliable (Tchan \& Jensen, 1963; Hill \& Postgate, 1969). Colony variations (massive and thin types), production of tenaceous gum, an apparent need for microaerophilic conditions during $\mathrm{N}_{2}$ fixation and some unknown factors have made the study of $\mathrm{N}_{2}$ fixation by D. gummosa difficult.

Autotrophic growth and $\mathrm{N}_{2}$ fixation were studied as two independent traits until the discovery of a $\mathrm{N}_{2}$-fixing hydrogen bacterium (Ooyama, 1971). Later, many $\mathrm{H}_{2}$-oxidizers were proved to fix $\mathrm{N}_{2}$ and many $\mathrm{N}_{2}$-fixers were shown to be capable of $\mathrm{H}_{2}$ oxidation. Some of the latter were also capable of autotrophic growth (Hanus et al., 1979). Pedrosa et al. (1980) were the first to report that $D$. gummosa can grow autotrophically by aerobic $\mathrm{H}_{2}$-dependent $\mathrm{CO}_{2}$ incorporation. In an autotrophically growing, $\mathrm{N}_{2}$-fixing $D$. gummosa, electrons donated by $\mathrm{H}_{2}$ will be channelled to $\mathrm{N}_{2}$ for $\mathrm{N}_{2}$ fixation, to $\mathrm{CO}_{2}$ for carbon fixation and to $\mathrm{O}_{2}$ as terminal electron acceptor for bioenergetic purposes. Hence the study of autotrophic $\mathrm{N}_{2}$ fixation should prove rewarding in providing information on the regulation of electron flow.

We have attempted to establish the optimum gas proportions and other cultural conditions for autotrophic growth and $\mathrm{N}_{2}$ fixation by $D$. gummosa. Initial attempts to grow the organism autotrophically were not reproducible and growth was very scanty whenever it occurred. This was shown to result from fast $\mathrm{O}_{2}$ depletion in the sealed growth chamber. Here we describe a continuous gas flow system giving consistent autotrophic growth of $D$. gummosa on agar surfaces, with provision for a continuous flow-through $\mathrm{C}_{2} \mathrm{H}_{2}$ reduction assay. The results obtained with this system provide information on reasons for the difficulty experienced in growing $D$. gummosa.

\section{METHODS}

Organism. Derxia gummosa strain 1-15 was originally obtained from H. L. Jensen, Statens Planteavls Laboratorium, Lyngby, Denmark.

Media and growth conditions. The medium of Tchan \& Jensen (1963) for D. gummosa consisting of ( $\mathrm{g}$ per litre of distilled water): $\mathrm{K}_{2} \mathrm{HPO}_{4}, 0.5 ; \mathrm{MgSO}_{4} .7 \mathrm{H}_{2} \mathrm{O}, 0.25 ; \mathrm{NaCl}, 0.1 ; \mathrm{FeSO}_{4} .7 \mathrm{H}_{2} \mathrm{O}, 0.1 ; \mathrm{CaCl}_{2}, 0.1 ; \mathrm{Na}_{2} \mathrm{MoO}_{4} .2 \mathrm{H}_{2} \mathrm{O}$, 
0.005 (final $\mathrm{pH} 7.0$ ) was used. Davis agar (Davis Gelatine NZ Ltd) was used as the solidifying agent, at $1.5 \%(\mathrm{w} / \mathrm{v})$ concentration unless mentioned otherwise.

(a) Solid culture. Twelve Petri dishes containing agar medium were inoculated with a suspension of autotrophically grown D. gummosa and placed in an anaerobic jar of 3.51 capacity (Oxoid; code HP11). The jar was evacuated and filled with the desired gas mixture and incubated at $30^{\circ} \mathrm{C}$.

(b) Liquid culture. D. gummosa was inoculated into $100 \mathrm{ml}$ liquid medium in a 1-litre flask, which was incubated at $30^{\circ} \mathrm{C}$ on a gyrotary shaker at 250 r.p.m. The mouth of the flask was sealed with a rubber bung fitted with a three-way stopcock, one free end of which was connected to an electrolytic generator. The other free end was used for evacuation, filling and sampling of gases. The decrease in pressure due to consumption of gases in the culture flask brought electrolyte (dilute $\mathrm{H}_{2} \mathrm{SO}_{4}$ ) into contact with the electrodes in an electrolytic generator which then produced $\mathrm{H}_{2}$ and $\mathrm{O}_{2}$ in the molar ratio of 2:1 until the gas space was at atmospheric pressure. According to Faraday's law of electrolysis, the products of electrolysis are proportional to the current consumed, which was measured with a copper coulometer connected in series in the circuit. Hence the loss of copper is proportional to the gas consumption in the flask. The partial pressure of $\mathrm{CO}_{2}\left(\mathrm{pCO}_{2}\right)$ within the flask was maintained at $0.1 \mathrm{~atm}$ by including in the flask a test tube containing $2 \mathrm{ml} \mathrm{NaHCO}_{3}$ solution $(2.5 \%$,w/v) buffered with $1 \mathrm{M}$-Tris at $\mathrm{pH} 8.5$.

(c) Biphasic culture. This was similar to liquid culture except that the flask contained $200 \mathrm{ml}$ agar medium (3\%, $\mathrm{w} / \mathrm{v}$, agar) overlaid with $100 \mathrm{ml}$ liquid medium.

Acetylene reduction assays. (a) Conventional technique. Vacutainer tubes $(10 \mathrm{ml})$ (Terumo Corp.) were evacuated and filled with 0.1 atm $\mathrm{C}_{2} \mathrm{H}_{2}, 0.05$ atm $\mathrm{CO}_{2}, 0.05$ atm $\mathrm{H}_{2}$ and complementary proportions of $\mathrm{O}_{2}$ and $\mathrm{N}_{2}$. A $1 \mathrm{ml}$ sample of a suspension of autotrophically growing D. gummosa was injected through the septum. Gas samples of $0.2 \mathrm{ml}$ were analysed by gas chromatography (Varian 3700) using a flame ionization detector to follow $\mathrm{C}_{2} \mathrm{H}_{4}$ formation.

(b) Flow-through assay. This was done in a plastic lunch box $(18.5 \times 12 \times 6 \mathrm{~cm})$ with a snaptight lid. Two brass $\mathrm{T}$-pieces having a septum and placed diagonally on either end of the box served as inlet and outlet ports. The gas mixture was supplied by a gas-mixing manifold attached to cylinders of $\mathrm{H}_{2}$, air, $\mathrm{CO}_{2}, \mathrm{~N}_{2}$ and $\mathrm{C}_{2} \mathrm{H}_{2}$. Pressures were controlled by two-stage pressure regulators. The gas flow rates were controlled by fine needle valves and monitored with flow meters. A solenoid valve was used to cut off the gas supply (Fig. 1). Eight Petri dishes with growing culture were placed in the box and gas mixture was passed through it at a constant flow rate of between 300 and $500 \mathrm{ml} \mathrm{min}^{-1}$.

Gas analysis. $\mathrm{H}_{2}, \mathrm{O}_{2}, \mathrm{CO}_{2}$ and $\mathrm{N}_{2}$ were separated on a CTR-1 concentric column $(1.83 \mathrm{~m} \times 3 \mathrm{~mm}$; Alltech Associates) using Ar as carrier gas $\left(30 \mathrm{ml} \mathrm{min}^{-1}\right)$ and measured with a thermal conductivity detector (Varian 3700$)$ at $101 \mathrm{~mA}$ current. The column oven temperature was $40^{\circ} \mathrm{C}$.

$\mathrm{CH}_{4}, \mathrm{C}_{2} \mathrm{H}_{4}$ and $\mathrm{C}_{2} \mathrm{H}_{2}$ were separated on a Porapak T column $(1.83 \mathrm{~m} \times 3 \mathrm{~mm})$ using $\mathrm{N}_{2}$ as carrier gas. The column oven temperature was $80^{\circ} \mathrm{C}$. A flame ionization detector (Varian 3700) was used to quantify the gases. All $\mathrm{C}_{2} \mathrm{H}_{4}$ concentrations were corrected with reference to the $\mathrm{CH}_{4}$ peak, to account for slight variations in flow rate of the assay system and for injection errors. The areas of the peaks were measured with an Autolab Minigrator (Spectra-Physics).

Hydrogenase activity. This was estimated by $\mathrm{H}_{2}$-dependent methylene blue reduction, measured photometrically. The reaction mixture was $5 \mathrm{ml}$ phosphate-buffered saline $(0.02 \mathrm{M}$-phosphate, $\mathrm{pH} 7.0)$ containing 20 p.p.m. methylene blue. The methylene blue solution was deoxygenated by boiling, flushed with $\mathrm{H}_{2}$ and equilibrated at $30^{\circ} \mathrm{C}$ for $30 \mathrm{~min}$. Ar was used as the filler gas when variable $\mathrm{H}_{2}$ concentrations were required. The reaction was started by adding $100 \mu \mathrm{l}$ D. gummosa suspension and the absorbance was measured at $660 \mathrm{~nm}$. The rate of methylene blue reduction was determined from the slope of the curve, which indicates the hydrogenase activity.

\section{RESULTS AND DISCUSSION}

\section{Chemoautotrophic growth}

Initial attempts to grow $D$. gummosa in Petri plates on agar containing mineral medium supplied with $\mathrm{H}_{2}, \mathrm{O}_{2}, \mathrm{~N}_{2}$ and $\mathrm{CO}_{2}(5: 1: 89: 5$, by vol.) yielded variable results. An analysis of the change in gas composition over the growing culture showed that $\mathrm{O}_{2}$ was rapidly depleted and frequent replenishments were necessary. Growth was much improved when the culture was grown in a perspex box $(50 \times 30 \times 31 \mathrm{~cm})$ under a stream of gas mixture. The box contained 60 80 agar plates seeded with $D$. gummosa. Fig. 1 is a schematic diagram of the flow-through apparatus used.

Since agar culture was not convenient for experimentation on cells, we also resorted to liquid culture, but this gave very poor growth. Since we had maintained similar cultural conditions in both solid and liquid cultures, it was apparent that agar in some way produced superior conditions for growth. 


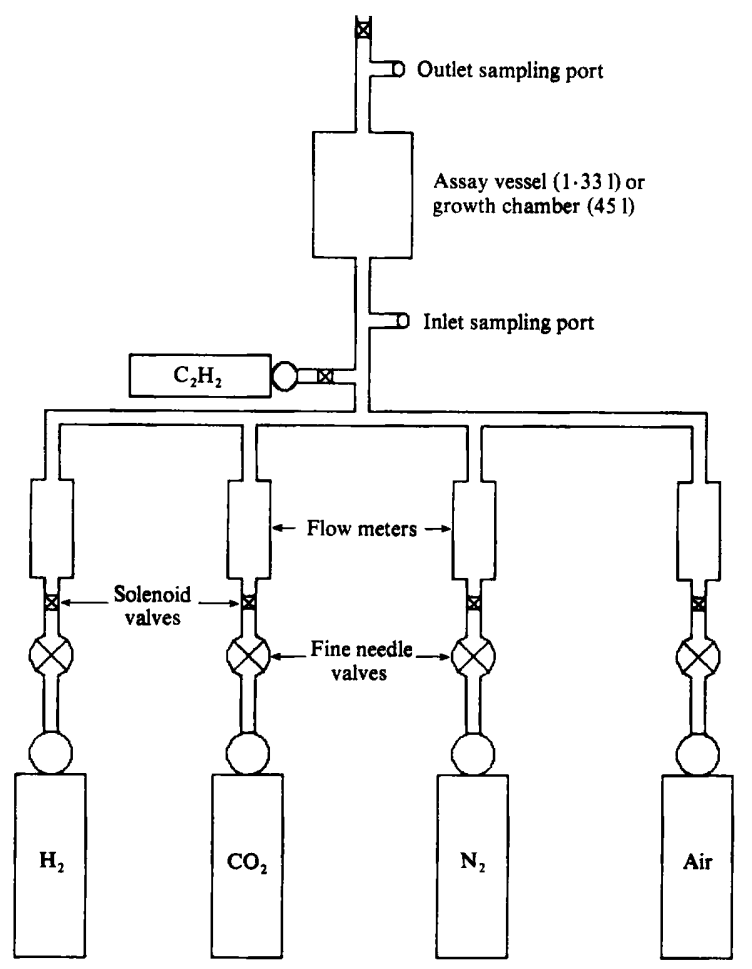

Fig. 1. Schematic diagram of a flow-through system for culturing or $\mathrm{C}_{2} \mathrm{H}_{2}$ reduction assay in a constant stream of a defined gas mixture.

\section{Effect of agar on autotrophic growth of D. gummosa}

We compared the growth of autotrophic D. gummosa in biphasic culture and liquid culture, with and without agar extract. Single flasks were used and the experiment was repeated three times, the same results being obtained each time. The results obtained from one of the experiments are presented in Fig. 2. Here, the loss of copper from the anode of the coulometer was taken as equivalent to the amount of electrolytically produced $\mathrm{H}_{2}$ and $\mathrm{O}_{2}(0.3855 \mathrm{~g}$ copper loss $\equiv 1 \mathrm{ml} \mathrm{H}_{2}+0.5 \mathrm{ml} \mathrm{O}_{2}$ ) and also as an indication of the hydrogenase activity of $D$. gummosa. The results indicated that a solid agar surface promoted growth and that an agar extract containing soluble material could not be substituted for it.

\section{Hydrogenase activity}

Effect of $\mathrm{C}_{2} \mathrm{H}_{2}$. Since $\mathrm{C}_{2} \mathrm{H}_{2}$ was reported to inhibit hydrogenase activity in $\mathrm{N}_{2}$-fixing bacteria (Smith et al., 1976), it was necessary to establish the extent of inhibition, if any, with $D$. gummosa. No significant differences were found in the rate of methylene blue reduction even at $0.5 \mathrm{~atm} \mathrm{C}_{2} \mathrm{H}_{2}$, indicating that no inhibition occurs.

Effect of partial pressure of $\mathrm{H}_{2}\left(\mathrm{pH}_{2}\right)$. The influence of $\mathrm{pH}_{2}$ on hydrogenase activity of whole cells is presented in Fig. 3. The hydrogenase activity increased linearly from $0.03 \mathrm{~atm} \mathrm{H}_{2}$, reaching a maximum velocity at 0.21 atm $\mathrm{H}_{2}$. The $\mathrm{pH}_{2}$ for half-maximal velocity was approximately $0 \cdot 15 \mathrm{~atm}$.

\section{Measurement of nitrogenase activity $\left(\mathrm{C}_{2} \mathrm{H}_{2}\right.$ reduction $)$}

Effect of partial pressure of $\mathrm{O}_{2}\left(\mathrm{pO}_{2}\right)$. Table 1 shows the effect of varying $\mathrm{pO}_{2}$ on $\mathrm{C}_{2} \mathrm{H}_{2}$ reduction by a suspension of autotrophically growing $D$. gummosa, using the conventional technique. The $\mathrm{C}_{2} \mathrm{H}_{4}$ concentrations indicated are mean values of triplicate tubes used in one of 


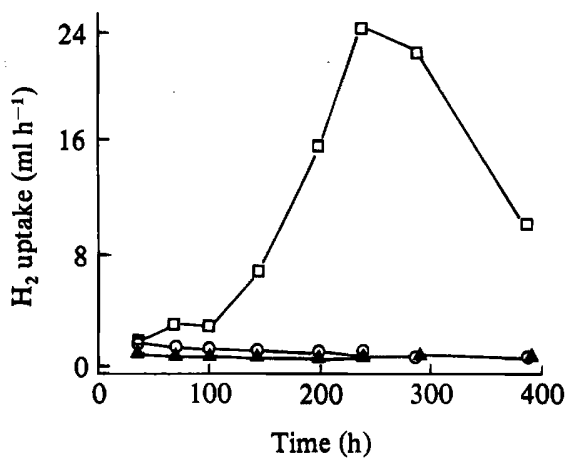

Fig. 2

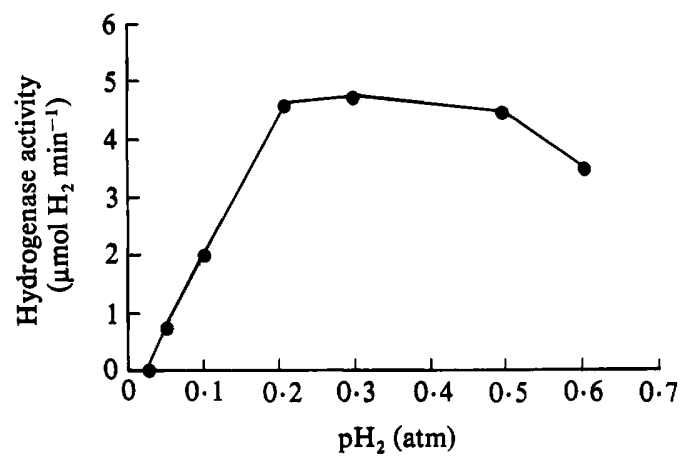

Fig. 3

Fig. 2. $\mathrm{H}_{2}$ uptake by autotrophically growing $D$. gummosa in liquid medium (A), liquid medium + agar extract $(O)$ or biphasic culture $(\square)$ as measured by loss of copper in a copper coulometer. The flask contained $0.8 \mathrm{~atm} \mathrm{H}_{2}, 0.02 \mathrm{~atm} \mathrm{O}_{2}, 0.1 \mathrm{~atm} \mathrm{CO}_{2}$ and 0.08 atm $\mathrm{N}_{2}$.

Fig. 3. Effect of $\mathrm{pH}_{2}$ on hydrogenase activity by autotrophically growing $D$. gummosa. Hydrogenase activity was calculated from the rate of change of $A_{660}$, using the molar absorption coefficient value of $\varepsilon_{660}=63000 \mathrm{l} \mathrm{mol}^{-1} \mathrm{~cm}^{-1}$. A cell concentration equivalent to $1-2 \mathrm{mg}$ protein was used per assay. A typical value for hydrogenase activity would be $3-5 \mu \mathrm{mol} \mathrm{H}_{2}$ (mg protein) ${ }^{-1} \mathrm{~min}^{-1}$.

Table 1. Effect of $\mathrm{pO}_{2}$ on $\mathrm{C}_{2} \mathrm{H}_{2}$ reduction by autotrophically growing $D$. gummosa, measured by the conventional technique

\begin{tabular}{|c|c|c|c|c|c|c|}
\hline \multirow{2}{*}{$\begin{array}{l}\text { Initial } \\
\mathrm{pO}_{2} \\
\text { (atm) }\end{array}$} & \multicolumn{5}{|c|}{$\begin{array}{c}\mathrm{C}_{2} \mathrm{H}_{4} \text { concn (p.p.m.) } \\
\text { at various times (h) } \\
\text { (means of three replicate tubes) }\end{array}$} & \multirow{2}{*}{$\begin{array}{c}\text { Final } \\
\mathrm{H}_{2} \text { concn } \\
(\%)\end{array}$} \\
\hline & 0 & 1 & 3 & 6 & 22 & \\
\hline 0 & 1.37 & $1 \cdot 32$ & $2 \cdot 13$ & 2.57 & $5 \cdot 37$ & 4.0 \\
\hline 0.005 & 1.36 & 1.21 & 2.03 & $3 \cdot 26$ & $4 \cdot 5$ & $2 \cdot 8$ \\
\hline 0.010 & $1 \cdot 18$ & 1.20 & 2.57 & 4.05 & $5 \cdot 11$ & $2 \cdot 2$ \\
\hline 0.020 & $1 \cdot 23$ & 1.24 & 4.53 & $7 \cdot 21$ & 10.98 & 0.4 \\
\hline 0.040 & $1 \cdot 35$ & $1 \cdot 12$ & $3 \cdot 37$ & 6.59 & 8.93 & 0.0 \\
\hline 0.070 & 1.45 & 1.29 & 1.66 & 4.86 & $10 \cdot 61$ & 0.0 \\
\hline $0 \cdot 100$ & 1.43 & $1 \cdot 26$ & 1.62 & $4 \cdot 27$ & $13 \cdot 3$ & $0 \cdot 0$ \\
\hline $0 \cdot 130$ & 1.54 & 1.4 & $4 \cdot 14$ & 9.67 & 28.03 & 0.0 \\
\hline
\end{tabular}

the experiments. $\mathrm{C}_{2} \mathrm{H}_{2}$ reduction was negligible in the initial stages, but increased with time after about $3 \mathrm{~h}$. The total amount of $\mathrm{C}_{2} \mathrm{H}_{4}$ increased with increase in initial $\mathrm{pO}_{2}$ up to the highest value tested, but concurrent analysis of the samples at $22 \mathrm{~h}$ showed that $\mathrm{H}_{2}$ was completely consumed in all the treatments above $0.04 \mathrm{~atm} \mathrm{O}_{2}$. Decreasing the cell density and/or increasing the surface area did not alleviate the problem of rapid $\mathrm{H}_{2}$ removal. Hence a flow-through $\mathrm{C}_{2} \mathrm{H}_{2}$ reduction assay system, where the gas mixture was continuously replenished, was designed (see Methods). This system was used in the experiments described hereafter. In this system each point of analysis (output - input value) represents the rate of $\mathrm{C}_{2} \mathrm{H}_{2}$ reduction, unlike the situation in a closed vessel (conventional technique) where $\mathrm{C}_{2} \mathrm{H}_{4}$ concentration is cumulative.

Culture plates briefly exposed to air during transfer from the culture chamber to the assay chamber initially did not reduce $\mathrm{C}_{2} \mathrm{H}_{2}$, but they regained their $\mathrm{C}_{2} \mathrm{H}_{2}$-reducing activity within $24 \mathrm{~h}$. Therefore plates were always incubated in the assay chamber for $24 \mathrm{~h}$, in an atmosphere containing $\mathrm{H}_{2}, \mathrm{O}_{2}, \mathrm{~N}_{2}$ and $\mathrm{CO}_{2}$, before $\mathrm{C}_{2} \mathrm{H}_{2}$ reduction assays were done.

Effect of partial pressure of $\mathrm{C}_{2} \mathrm{H}_{2}\left(p \mathrm{C}_{2} \mathrm{H}_{2}\right)$. The $\mathrm{C}_{2} \mathrm{H}_{2}$ reduction rate increased with increase in $\mathrm{pC}_{2} \mathrm{H}_{2}$ from 0.022 atm to $0.081 \mathrm{~atm}$, above which value there was no significant change (Fig. 4). Decrease in $\mathrm{pC}_{2} \mathrm{H}_{2}$ did not decrease the rate of $\mathrm{C}_{2} \mathrm{H}_{2}$ reduction within the time tested. This 


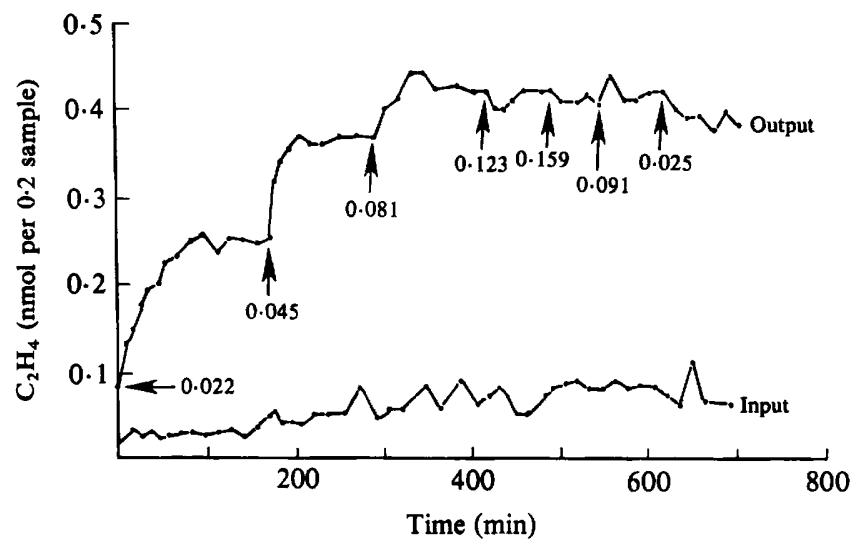

Fig. 4. Effect of $\mathrm{pC}_{2} \mathrm{H}_{2}$ on $\mathrm{C}_{2} \mathrm{H}_{2}$ reduction in autotrophically growing $D$. gummosa in a flow-through assay system. Readings of $\mathrm{C}_{2} \mathrm{H}_{4}$ concentration were taken at $15 \mathrm{~min}$ intervals. Arrows indicate the times at which the $\mathrm{pC}_{2} \mathrm{H}_{2}(\mathrm{~atm})$ was altered to the value indicated beneath the arrow. $\mathrm{A} 17 \mathrm{~d}$ old culture grown on 0.364 atm $\mathrm{H}_{2}, 0.03 \mathrm{~atm} \mathrm{O}_{2}, 0.05 \mathrm{~atm} \mathrm{CO}_{2}$ and $0.556 \mathrm{~atm} \mathrm{~N}_{2}$ was used. $\mathrm{C}_{2} \mathrm{H}_{2}$ and $\mathrm{N}_{2}$ were in complementary proportions during the experiment.

could be due to the 'memory effect' caused by high solubility of $\mathrm{C}_{2} \mathrm{H}_{2}$ in water. The $\mathrm{pC}_{2} \mathrm{H}_{2}$ of $0.1 \mathrm{~atm}$ used in the following experiments was sufficient to saturate the nitrogenase enzyme.

Effect of $\mathrm{pO}_{2}$. Plate cultures of D. gummosa equilibrated for $24 \mathrm{~h}$ in an atmosphere of 0.048 atm $\mathrm{O}_{2}$ were exposed to various $\mathrm{pO}_{2}$ values by changing the flow rates of air and $\mathrm{N}_{2}$ complementary to each other. The results of $\mathrm{C}_{2} \mathrm{H}_{4}$ analyses at $10-20 \mathrm{~min}$ intervals at the inlet and outlet ports are shown in Fig. 5. At 0.048 atm $\mathrm{O}_{2}, \mathrm{C}_{2} \mathrm{H}_{2}$ reduction activity increased initially and stabilized after 2 to $3 \mathrm{~h}$. An increase in $\mathrm{pO}_{2}$ increased the rate of $\mathrm{C}_{2} \mathrm{H}_{2}$ reduction, which stabilized at a new higher value, and lowering the $\mathrm{pO}_{2}$ to $0.043-0.048$ atm caused a rapid decline in the activity, until the original steady-state value was attained.

In a further experiment, with a different culture grown at $0.043 \mathrm{~atm} \mathrm{O}_{2}$, the cells were starved of $\mathrm{O}_{2}$ for $2 \mathrm{~h}$ before being exposed to increasing $\mathrm{pO}_{2}$ values. With this culture, steady rates of $\mathrm{C}_{2} \mathrm{H}_{2}$ reduction were often achieved within $40 \mathrm{~min}$ and, by not returning to a constant 'baseline' $\mathrm{pO}_{2}$, it was possible to use a greater number of different $\mathrm{pO}_{2}$ values (Fig. 6). The steady-state rates of $\mathrm{C}_{2} \mathrm{H}_{2}$ reduction again appeared to increase with increase in $\mathrm{pO}_{2}$ up to $0.105 \mathrm{~atm}$, but activity decreased at $0.123 \mathrm{~atm} \mathrm{O}_{2}$. This is probably due to the sensitivity of hydrogenase towards $\mathrm{O}_{2}$ in this range rather than to denaturation of nitrogenase, since lowering the $\mathrm{pO}_{2}$ to $0.046 \mathrm{~atm}$ restored the $\mathrm{C}_{2} \mathrm{H}_{2}$ reduction activity. The reason for the rise of activity at $0.046 \mathrm{~atm}$ $\mathrm{O}_{2}$, above the value observed previously at a similar $\mathrm{pO}_{2}$, is not apparent and is at variance with the results shown in Fig. 5. However, the results confirm that $\mathrm{C}_{2} \mathrm{H}_{2}$ reduction increases with increasing $\mathrm{pO}_{2}$.

Effect of $\mathrm{pH}_{2}$. Cells were starved of $\mathrm{H}_{2}$ for $2 \mathrm{~h}$ and $\mathrm{C}_{2} \mathrm{H}_{2}$ reduction was followed at various $\mathrm{pH}_{2}$ values. No $\mathrm{C}_{2} \mathrm{H}_{2}$ reduction could be detected, indicating that nitrogenase was inactivated. It was reasoned that, in the absence of $\mathrm{H}_{2}$, nitrogenase would be inactivated by $\mathrm{O}_{2}$. The experiment was repeated with descending $\mathrm{pH}_{2}$ (Fig. 7). The cells had previously been growing at $0.231 \mathrm{~atm} \mathrm{H}_{2}$ before the atmosphere was changed to 0.527 atm $\mathrm{H}_{2}$. The $\mathrm{N}_{2}$ flow rate was adjusted to compensate for the increased $\mathrm{H}_{2}$ flow rate. Initially, at 0.527 atm $\mathrm{H}_{2}$, the $\mathrm{C}_{2} \mathrm{H}_{2}$ reduction rate increased during $\mathrm{C}_{2} \mathrm{H}_{2}$ equilibration. With decreasing $\mathrm{pH}_{2}$ to 0.147 atm no marked effect was observed. However, when the $\mathrm{pH}_{2}$ was reduced to $0.074 \mathrm{~atm}$, the rate of $\mathrm{C}_{2} \mathrm{H}_{2}$ reduction fell drastically, and essentially no activity was recorded following change to $0.027 \mathrm{~atm}$ $\mathbf{H}_{2}$. 


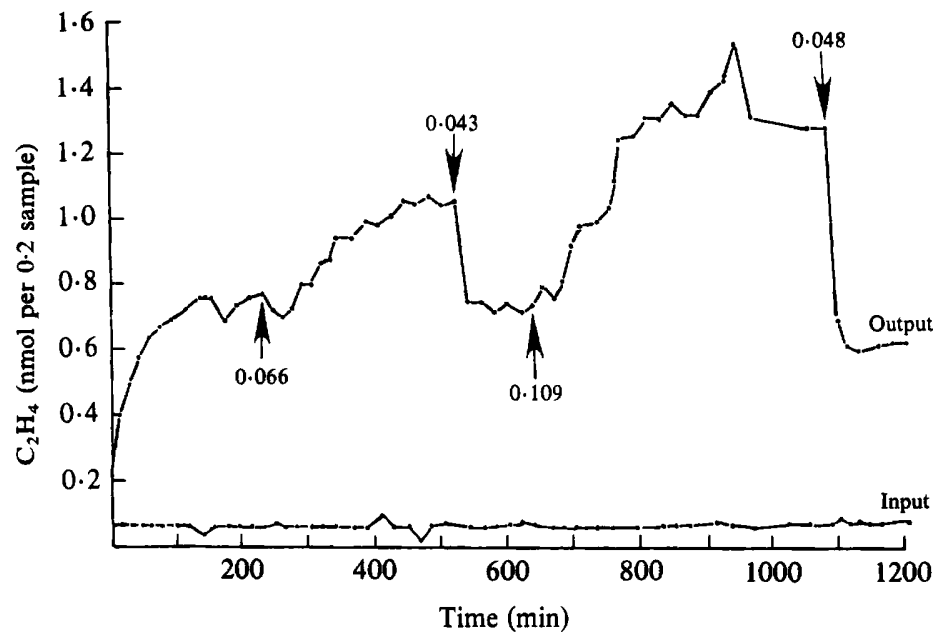

Fig. 5. Effect of $\mathrm{pO}_{2}$ on $\mathrm{C}_{2} \mathrm{H}_{2}$ reduction by autotrophically growing $D$. gummosa in a flow-through assay system. Readings of $\mathrm{C}_{2} \mathrm{H}_{4}$ concentration were taken at 15-20 min intervals except at $1015 \mathrm{~min}$, where a 90 min interval was used. Arrows indicate the time at which the $\mathrm{pO}_{2}(\mathrm{~atm})$ was changed to the value beneath the arrow. A $13 \mathrm{~d}$ old culture grown on $0.24 \mathrm{~atm} \mathrm{H}_{2}, 0.048 \mathrm{~atm} \mathrm{O}_{2}, 0.05 \mathrm{~atm} \mathrm{CO}_{2}$ and $0.66 \mathrm{~atm} \mathrm{~N}_{2}$ was used.

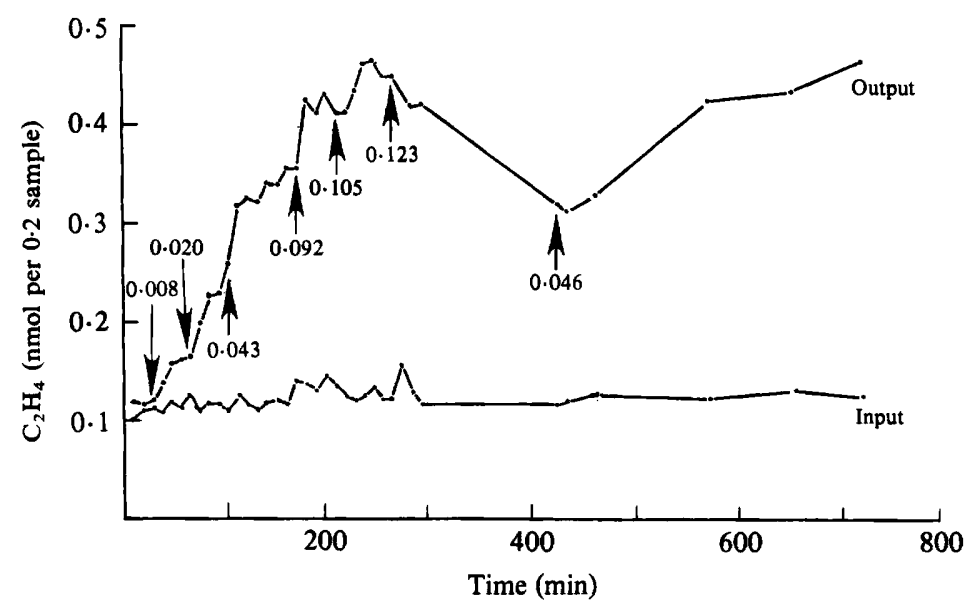

Fig. 6. Effect of $\mathrm{pO}_{2}$ on $\mathrm{C}_{2} \mathrm{H}_{2}$ reduction by autotrophically growing $D$. gummosa in a flow-through assay system. Readings of $\mathrm{C}_{2} \mathrm{H}_{4}$ concentration were taken at $10 \mathrm{~min}$ intervals up to $315 \mathrm{~min}$, after which the interval was variable. Arrows indicate the time at which $\mathrm{pO}_{2}(\mathrm{~atm})$ was changed to the value indicated beneath the arrow. A $14 \mathrm{~d}$ old culture grown on $0.233 \mathrm{~atm} \mathrm{H_{2 }}, 0.043 \mathrm{~atm} \mathrm{O}, 0.05 \mathrm{~atm} \mathrm{CO}_{2}$ and $0.674 \mathrm{~atm} \mathrm{~N}_{2}$ was used.

Thus the reduction of $\mathrm{C}_{2} \mathrm{H}_{2}$ was absolutely dependent upon the presence of $\mathrm{H}_{2}$. It is interesting that the $\mathrm{C}_{2} \mathrm{H}_{2}$ reduction rate did not start decreasing unti the $\mathrm{pH}_{2}$ was well below the $K_{\mathrm{m}}$ of hydrogenase for $\mathrm{H}_{2}$ as seen from Fig. 3. This is consistent with the theory that $\mathrm{C}_{2} \mathrm{H}_{2}$ reduction at this $\mathrm{pH}_{2}$ is limited by the electrons donated by $\mathrm{H}_{2}$. A similar observation was made by Berndt \& Wölfle (1978), who studied the effect of $\mathrm{pH}_{2}$ on $\mathrm{C}_{2} \mathrm{H}_{2}$ reduction by Xanthobacter autotrophicus in chemostat culture.

$\mathrm{H}_{2}$ also helps to prevent $\mathrm{O}_{2}$ damage to nitrogenase. In previous experiments the rate of $\mathrm{C}_{2} \mathrm{H}_{2}$ reduction decreased at $\mathrm{O}_{2}$ concentrations above $10-12 \%$. This may have been due to the sensitivity of hydrogenase to $\mathrm{O}_{2}$ in this range (Bowien \& Schlegel, 1981). In the absence of $\mathrm{H}_{2}$, 


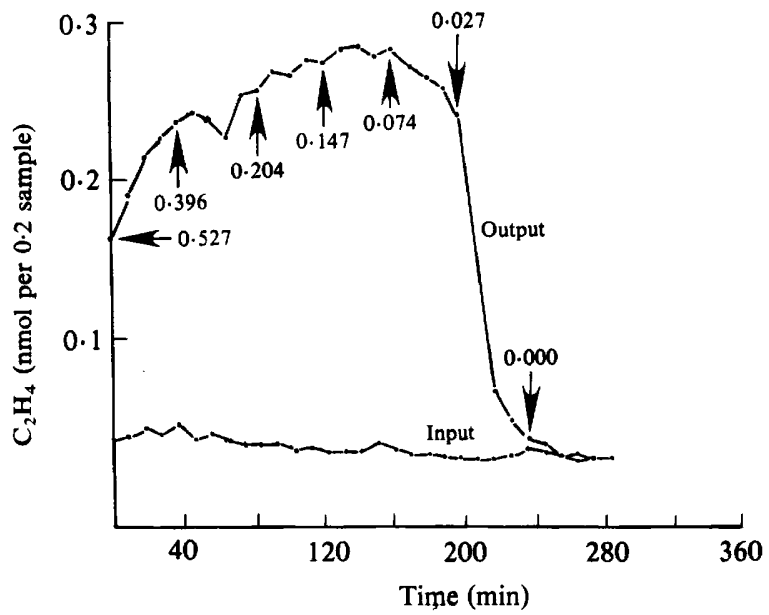

Fig. 7. Effect of $\mathrm{pH}_{2}$ on $\mathrm{C}_{2} \mathrm{H}_{2}$ reduction by autotrophically growing $D$. gummosa in a flow-through assay system. Readings of $\mathrm{C}_{2} \mathrm{H}_{4}$ concentration were taken at $10 \mathrm{~min}$ intervals. Arrows indicate the time at which the $\mathrm{pH}_{2}$ (atm) was changed to the value beneath the arrow. A $13 \mathrm{~d}$ old culture grown on $0.231 \mathrm{~atm} \mathrm{H}_{2}, 0.049 \mathrm{~atm} \mathrm{O}_{2}, 0.05 \mathrm{~atm} \mathrm{CO}_{2}$ and $0.67 \mathrm{~atm} \mathrm{~N}_{2}$ was used.

no $\mathrm{C}_{2} \mathrm{H}_{2}$ reduction occurred. This could be due either to $\mathrm{O}_{2}$ sensitivity of nitrogenase, which is prevented when $\mathrm{H}_{2}$ is present, or to severe limitations in the supply of ATP and reductant to nitrogenase, in the absence of $\mathrm{H}_{2}$. These data now enable us to establish a set of conditions that can yield reasonable autotrophic growth of $\mathrm{N}_{2}$-fixing D. gummosa. Studies are in progress to define further the $\mathrm{O}_{2}$ and $\mathrm{H}_{2}$ requirements for autotrophic growth and $\mathrm{N}_{2}$ fixation, factors which regulate the allocation of electrons from $\mathrm{H}_{2}$ to various electron acceptors, and to determine the pathways of electron transfer.

H.N.R.S. thanks the University of Sydney for support by awarding a Thomas Lawrence Pawlett Scholarship during the course of this investigation.

\section{REFERENCES}

BerNDT, H. \& WölfLe, D. (1978). Hydrogenase: its role as electron generating enzyme in the nitrogen fixing ; bacterium Xanthobacter autotrophicus. In Hydrogenases: Their Catalytic Activity, Structure and Function, pp. 327-351. Edited by H. G. Schlegel \& K. Schneider. Göttingen: Erich Goltze.

Bowien, B. \& Schlegel, H. G. (1981). Physiology and biochemistry of aerobic hydrogen-oxidizing bacteria. Annual Review of Microbiology 35, 420-421.

Hanus, F. J., Maier, R. J. \& Evans, H. J. (1979). Autotrophic growth of hydrogen-uptake positive strains of Rhizobium japonicum in an atmosphere supplied with hydrogen gas. Proceedings of the National Academy of Sciences of the United States of America 76, 1788-1792.

Hill, S. \& Postgate, J. R. (1969). Failure of putative nitrogen fixing bacteria to fix nitrogen. Journal of General Microbiology 58, 277-285.
Ooyama J. (1971). Simultaneous fixation of carbon dioxide and nitrogen in the presence of hydrogen and oxygen by a bacterium. Report of the Fermentation Research Institute no. 39, 43-44.

Pedrosa, F. O., Döbereiner, J. \& Yates, M. G. (1980). Hydrogen-dependent growth and autotrophic carbon dioxide fixation in Derxia. Journal of General Microbiology 119, 547-551.

SMith, L. A., Hill, S. \& Yates, M. G. (1976). Inhibition by acetylene of conventional hydrogenase in nitrogen fixing bacteria. Nature, London 262, 209210.

TChan, Y. T. \& Jensen, H. L. (1963). Studies of nitrogen fixing bacteria. VIII. Proceedings of the Linnean Society of New South Wales 38, 379-385. 